\title{
İntramedüller olarak uygulanan trokanterik çivi
}

\section{Trochanteric intramedullary nail}

\author{
Oğuz Şükrü Poyanlı \\ İstanbul Medeniyet Üniversitesi Tıp Fakültesi, Ortopedi ve Travmatoloji Ana Bilim Dalı, İstanbul \\ Göztepe Prof. Dr. Süleyman Yalçın Şehir Hastanesi, Ortopedi ve Travmatoloji Kliniği, İstanbul
}

\begin{abstract}
Buluş, tıp alanında, ortopedi ve travmatoloji dalında, erişkin ve yaşlılarda görülen femur (uyluk kemiği) üst ucunu ilgilendiren trokanterik bölge kırıklarında kullanılmak üzere, intramedüller olarak (kemik iliği kanalına) uygulanan bir çivi yapılanması ile ilgilidir. Konuyla ilgili faydalı model dosyası paylaşılmıştır. Bu buluş sayesinde, uygulanan intramedüller çiviler ile hastanın anatomik yapısının farklılıklarından kaynaklanan ek kırık oluşması, redüksiyonun bozulması, distalde stres yaratması gibi giriş yeri komplikasyonlarının en aza indirilmesi sağlanmaktadır.
\end{abstract}

Anahtar sözcükler: faydalı model; proksimal femur kırıkları; intramedüller çivileme; çivi-anatomi uyumsuzlukları

\section{T. C. Türk Patent Enstitüsü'ne Faydalı Model Belgesi için Başvuru Bilgileri[ ${ }^{1]}$}

Başvuru bilgileri Tablo 1'de gösterilmiştir. ${ }^{[1]}$

Tablo 1. Başvuru bilgileri ${ }^{[1]}$

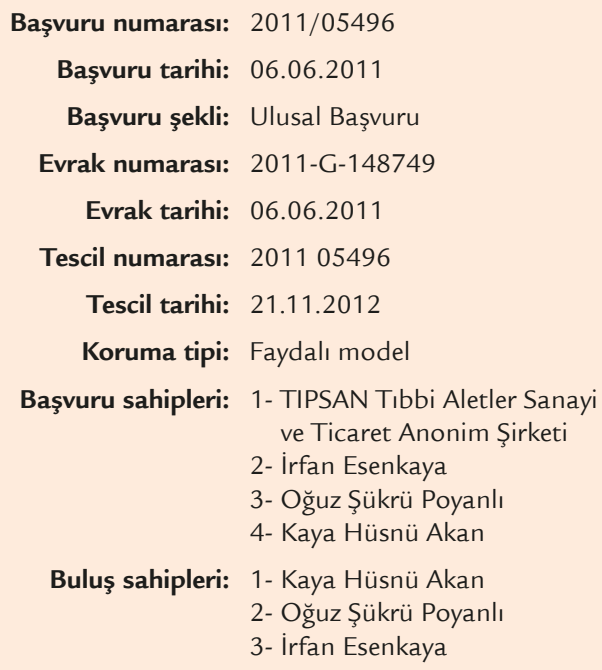

This invention pertains to the area of orthopaedics and traumatology of the medical sciences. The present invention relates to an intramedullary cavity nail for the treatment of proximal femoral fractures in the trochanteric region in adults and the elderly patients. The utility model file has been shared. This invention minimizes the complications of the entry point such as additional fracture, loss of reduction and stress in the distal part of the fracture that is caused by mismatches between the nail and patient's anatomy.

Key words: utility model; proximal femur fractures; intramedullary nailing; mismatches between nail and anatomy

\section{PATENT BELGESI - No: TR 201105496 U[1]}

\section{Teknik Alan ${ }^{[1]}$}

"Bu buluş, tıp alanında, ortopedi ve travmatoloji dalında, erişkin ve yaşlılarda görülen femur (uyluk kemiği) üst ucunu ilgilendiren trokanterik bölge kırıklarında kullanılmak üzere, intramedüller olarak (kemik iliği kanalına) uygulanan bir çivi yapılanması ile ilgilidir.

Buluş özellikle femurun (uyluk kemiğinin) üst ucunun (trokanter bölge) kanal içi şekline uyum sağlayacak şekilde bu bölgenin anatomik yapısı da göz önüne alınarak eğimli olarak oluşturulan, să̆ ve sol femur üst uçları için ayrı ayrı olmak üzere farklı çap ve boylarda olabilen, femur boynu anteversiyonu ile uyumlu olacak şekilde boyun ve başa giden en az bir sabitleme elemanı deliği ve alt uçta transvers (vücudun uzunlamasına olan eksenine dik açı yaparak) istikamette sabitleme elemanı göndermeye uygun, sabitleme elemanı deliklerinden oluşan kanal için uygulamalı bir çivi yapılanması ile ilgilidir."

\section{Tekniğin Bilinen Durumu[1]}

"Kırık, dıştan veya içten etki eden kuvvetlerle kemik dokusunda oluşan ayrilma veya bu sebeplerle kemiğin anatomik

- İletişim adresi: Prof. Dr. Oğuz Şükrü Poyanlı, İstanbul Medeniyet Üniversitesi Tıp Fakültesi, Ortopedi ve Travmatoloji Ana Bilim Dalı, Kadıköy, İstanbul Tel: 0532 - 3170750 e-posta: opoyanli@gmail.com ORCID iD: 0000-0002-4126-0306

- Geliș tarihi: 5 Aralık $2020 \quad$ Kabul tarihi: 14 Aralık 2020 
bütünlüğünün ve devamlılığının bozulmasıdır. Kemikteki kırılma etki eden kuvvetlerin derecesine ve kemiğin şoku absorbe edebilme yeteneğine göre ufak bir çatlaktan bir veya birçok kemiğin kırılmasına; hatta yakın eklemlerde çıkı̆̆ın eşlik etmesine kadar değişiklik gösterebilmektedir. Femur (uyluk kemiği), insan vücudundaki en uzun ve en kuvvetli kemiktir. Uzunluğunun büyük bölümü hemen hemen silindirik ve öne doğru eğimli olan femur proksimalinde (üst ucunda) kısa bir boyun üzerinde yuvarlak bir kafa (baş) yer almaktadır.

Günümüzde tıp alanında, erişkin kalça bölgesi kırıkları olarak da geçen femur (uyluk kemiği) proksimaline (üst ucuna) ait trokanterik bölge kırıklarının tespitinde birçok sistem ve yöntem kullanılmaktadır. Bu bölgede oluşan kırıklarda cerrahi yöntem uygulamanın amacı, kırığın anatomik olarak redüksiyonunu sağladıktan sonra yerinden oynamış bir kırığın ya da çıkmış bir eklemin normal anatomik pozisyonuna getirilmesinden sonra mekanik olarak güçlü ve iyi uygulanmış bir sistem ile kırığın tespitinin sağlanmasıdır. Bu amaçla, kırığın tipine, hastanın yaşına ve aktivite derecesine göre değişmek üzere sabit açılı kamalı plaklar, değişken açılı kamalı plaklar, kilitli-kilitsiz kayıcı plak-vida sistemleri, kayıcı ve kompresyon yapıcı vida-plak sistemleri, trokanter stabilize edici kalça plağı kombinasyonları, intramedüller çiviler, eksternal fiksatörler ve çeşitli tip protezler yaygın olarak kullanılmaktadır.

Bahsedilen sistemler içerisinde, diğer uzun kemik kırıklarında olduğu gibi trokanterik bölge kırıklarının tespitinde de intramedüller olarak yani kemik iliği kanalı içerisine gönderilen sistemler diğer sistem ve yöntemler kadar yaygın olarak kullanılmaktadır. Bu amaçla tarihsel gelişimi içerisinde femur alt ucundan uygulanan Ender çivileri dışında femur üst ucundan uygulanan rijid kondilosefalik çiviler, standart ve trokanterik Gamma çivileri, intramedüller kalça çivi ve vidasI, trokanterik antegrad çivi (TAN ve iNTERTAN), proksimal femoral çivi (PFN), proksimal femoral çivi - antirotasyon (PFN-A), Vero-nail çivisi, proksimal femoral intramedüller çivi (PROFIN) bulunmaktadır.

Intramedüller çivileme; kırık yerini açarak (açık) ya da hiç açmadan (kapalı) femur kemiğinin içine tüp gibi bir çivi yerleştirilmesidir. Biyomekanik olarak, intramedüller çivileme uygulamasında, çivinin medial aksa yakın yerleşimi nedeni ile daha etkili yük nakli sağlanmakta ve kaldıraç kolunun kısa olması sayesinde çiviye binen yük azaltılmaktadır. Böylelikle mekanik yetmezlik riski azaltılmaktadır. Kontrollü kırık impaksiyonu gibi mekanik avantajları ile ekstramedüller (kemik kanalı dışından) uygulanan tespit yöntemine göre intramedüller çivileme biyomekanik olarak daha üstündür.

Kırığın tipine göre kilitli çivileme ya da kilitsiz çivileme yapılmaktadır. Kilitli çivilemede femur içindeki tüp gibi çivi kırığın üst ve alt kısmından kemiğe vidalarla tespit edilerek kırık tam olarak sabitlenmektedir. Kilitli çivileme özellikle parçalı ve oblik kırıklarda kısalmayı önlemek için uygulanmaktadır. Özellikle kırıkta kısalma riski olmayan transvers femur kırıklarında ise intramedüller çivi kemiğe ya kırığın üstünden ya da altında vida ile tespit edilerek rotasyon engellenirken tek vida nedeni ile diğer parçanın kaymasına izin verildiğinden hasta bastıkça kırık uçlarının yaklaşması sağlanmaktadır.

Kemik iliği kanalı içerisinden uygulanan intramedüller çivi sistemlerinde ameliyatın kısa sürmesinin yanı sıra az kan kaybına neden olması, ameliyat sonrası hastanın hızlı bir şekilde ayăga kalkması ve günlük yaşama kolaylıkla geri dönebilmesi söz konusudur. Özellikle yaşlı hastaların ameliyattan hemen sonra tam yük vererek yatak dışına çıkartılması ve hareket etmeleri mümkün olmaktadır. Bahsedilen sebeplerden ötürü, erişkin ve yaşlıların trokanter bölgesi kırıklarının tedavisinde kemik iliği kanalı içerisinden uygulamalı çiviler yaygın olarak kullanılmaktadır.

Literatürde, konu ile ilgili yer alan patentlerden biri; EP0853923 (A1) numaralı Avrupa Patent başvurusudur. Söz konusu patent, femurdaki proksimal kırıkların tedavisi için kemik iliği boşluğuna takılmak üzere geliştirilen bir çivi ile ilgilidir. Bahsedilen çivi, uzatılmış katı gövdesi proksimal (merkeze yakın) bir kısımdan ve ona bağlı olan bir distal (merkeze uzak) kısımdan meydana gelmektedir. Proksimal kısmın üzerinde femurun (uyluk kemiği) boyun şeklinde incelme gösteren bölümünün sağlam ve kımıldayamayacak bir şekilde desteklenmesi için öngörülen vidaların takılabilmesini sağlayan en azından bir delik içermektedir. Benzer şekilde, distal kısmının üzerinde de uyluk kemiğinin merkezden uzak bölümünün sağlam ve kımıldamayacak şekilde desteklenmesinde kullanılan en azından bir diafiz (kemik gövdesi) vidasının takılabilmesi için en azından bir distal delik bulunmaktadır. Çivinin karakteristik özelliği, proksimal kısmın çapının esas itibarı ile sabit olması ve uyluk kemiğinin içindeki nispeten sınırlı uzunlamasına boşluğun içine sağlam ve sabit bir şekilde tespit edilerek adapte edilmiş olmasıdır. Distal kısmın çapı da sabit olup, proksimal kısmın çapından daha küçüktür. Bu sayede delmeye gerek kalmadan uyluk kemiğinin içindeki kanalı içerisine gireceği iddia edilmektedir. Ancak, çivinin geçtiği kemik kanalı, kemiğin yapısı gereği daralmakta ve çivinin bu kanalda ilerlemesi zorlaşmaktadır. Bunu engellemek üzere çivinin esnemesini ya da ucunun daralmasını sağlayan bir yapı oluşturulmamıştır. Bununla birlikte söz konusu proksimal bağlantı elemanları proksimal parçaya birbirine paralel olacak şekilde değil, yakınsayarak takılmaktadır. Bu işlem femur boynundaki kırı̆̆ın açılmasını engellemek üzere yapılmaktadır. Ayrıca, iki sabitleme elemanı arasındaki açı, çivinin distal kısmındaki aksına aynı paralelde $(x-y)$ düzleminde $15^{\circ}$ 'dir.

EP1639953 (B1) numaralı Avrupa Patent başvurusu, çatlağı azdan çoğa kadar trokantere uzanan pertrokanterik kırıklar, medial kırıklar ve femur boynunun tabanındaki kırıklar ve benzerleri gibi proksimal femur kırıklarının tedavisi için endomedüller bir çivi ile ilgilidir. 
TR199900333 numaralı, "Femur ve tibianın cisim klrıkları ile rekonstrüktif cerrahisinde kullanılan intramedüler kilitli çiviler" başlıklı ulusal faydalı model başvurusu ise tibia ve femur çivileri kilitli statik, dinamik, kompresif ve bunların kombinasyonlarına izin veren skopi gerektirmeyen çiviler ile ilgilidir. Bahsedilen femur çivisi anatomik eğimli, tibia çivisi proksimalinde $15^{\circ}$ öne eğimli, uсu ise kama şeklinde olan, her ikisi de oluklu dolu yapıda çivilerdir.”

\section{Tekniğin Bilinen Durumunda, Femur Kırıklarında Kullanılmak Üzere Geliştirilen Çivilerden Bazıları ${ }^{[1]}$}

"Trokanterik antegrad çivi (TAN): Proksimal çapı 13 $\mathrm{mm}$ ve uzunluğu $15 \mathrm{~cm}$ 'dir. Distalde 10 ve $11,5 \mathrm{~mm}$ çap seçenekleri vardır. Mediolateral eğimi $5^{\circ}$, çivi-vida açısı $135^{\circ}$ 'dir. INTERTAN tasarımında mediolateral (yana doğru) eğimi $4^{\circ}$ 'dir. Boyun vidası kendi içerisinde kilitlenen ikili bir vida kombinasyonudur.

Proksimal femoral nail (PFN): Uzunluğu 240 mm, proksimal çapı $17 \mathrm{~mm}$ 'dir. Distalde 10, $11 \mathrm{ve} 12 \mathrm{~mm}$ çap seçenekleri vardır. Proksimalde femur boynuna biri asıl tespiti sağlayan $11 \mathrm{~mm}$ çapında, diğeri rotasyonu önlemek üzere $6,5 \mathrm{~mm}$ çapında olmak üzere farklı iki çapta vida gönderilmektedir. Distal vidalar dinamik ve statik olarak kilitlenebilmektedir. Bu çivinin proksimal kilitleme mekanizması, açık olan kırık hattının çektirilmesine izin vermemektedir. Ayrıca başa giden vidaların kırık hattında oynama olması durumunda geriye doğru kayma yaparak "Z" etkisi veya ters "Z" etkisi adı verilen komplikasyona yol açmaktadır.

Proksimal femoral nail-antirotasyon (PFN-A): PFN'den sonra geliştirilen yeni bir çividir. Femur boynuna gönderilen vida helikal şekillidir. Tek vida ile rotasyonel stabilite sağlanmaktadır. Çivinin boyu 240 mm, proksimal çapı 17 mm'dir. Distalde 10, 11 ve $12 \mathrm{~mm}$ çap seçenekleri vardır. Mediolateral eğimi $6^{\circ}$, çivi-vida açısı $130^{\circ}$ 'dir. Distal vidalar dinamik ve statik olarak kilitlenebilmektedir. Bu çivinin proksimal kilitleme vidasının helikal şekli ve çapının büyük olması özellikle yaşlı ve kısa boylu hastalarda osteoporozun da etkisi ile baş ve boyun kısmında yırtılma, mevcut implantların uzun kalması nedeniyle tespitin imkansız hale gelebilmesine yol açmaktadır.

Vero nail: Çivi boyu $200 \mathrm{~mm}$, proksimal çapı $15 \mathrm{~mm}$, distal çapı $10 \mathrm{~mm}$ 'dir. Mediolateral eğimi $5^{\circ}$, çivi-vida açısı $128^{\circ}$ 'dir. Statik ve dinamik olarak kilitlenebilirdir. Proksimal boyun vidası istendiği takdirde 120 derece açıda gönderilen vida ile konverjan seçeneğinde kullanılabilir.

Proksimal femoral intramedüller nail (PROFIN): Çivinin $220 \mathrm{~mm}$ ve $250 \mathrm{~mm}$ olmak üzere iki farklı boy ve $10 \mathrm{~mm}, 11 \mathrm{~mm}$ ve $12 \mathrm{~mm}$ olmak üzere üç farklı distal çap seçeneği vardır. Mediolateral eğimi $6^{\circ}$ 'dir. Çivi-vida açısı $126^{\circ}$ 'dir. Çivinin distalinde, esnemeye izin veren, femur distalinde stres yoğunlaşmasını azaltan bir yarık vardır. Boyuna gönderilen vidaların her ikisi ile de ayrı ayrı kompresyon uygulanabilmektedir. Distalde dinamik ve statik kilitleme seçenekleri vardır. Bu çivinin anatomik olmaması nedeniyle özellikle kısa boylu hastalarda veya trokanterik bölgede parçalanmanın olduğu kırıklarda aynı anda iki vida ile kilitleme seçeneğinin kullanılamaması söz konusudur. Proksimalde kalacak olan baş vidası boyunun üst kısmını yırtarak dışarıya çıkabilmektedir.

Mevcut teknikte kullanılan trokanterik bölge çivilerinin uygulamaları sırasında, çivide distal bölge ve proksimal parçalar arasında çivinin kemik kanalında rahat ilerlemesini sağlamak üzere bir açı değeri bulunmamaktadır. Bu açıya sahip olmadıklarından başa yollanan vidaların başı tam merkezlemesini sağlayamamaları söz konusudur. Bu nedenle bu çivilerin uygulamasında başa önce bir kılavuz tel yollanarak skopi cihazı ile hem ön-arka hem de yan görüntülerde bu kılavuz telin tam olarak merkezlemesi gerekirse de tekrar tekrar motor ile delinerek sağlanmaktadır. Bu durum ise hastanın uzun süre radyasyona maruz kalması anlamına gelmektedir.

Sonuç olarak, femur kırı̆̆ı tedavisinde, intramedüller olarak (kemik iliği kanalına) uygulanmak üzere kullanılan çivi yapılanmalarında geliştirmelere gidilmekte, bu nedenle yukarıdaki değinilen dezavantajları ortadan kaldıracak ve mevcut sistemlere çözüm getirecek yeni yapılanmalara ihtiyaç duyulmaktadır."

\section{Buluşun Amaci ${ }^{[1]}$}

"Mevcut buluş, yukarıda bahsedilen gereksinimleri karşılayan, tüm dezavantajları ortadan kaldıran ve ilave bazı avantajlar getiren intramedüller trokanterik çiviler ile ilgilidir.

Buluşun bir amacı, farklı uzanımlı kırık tiplerinde ve hastanın boyu ile orantılı olarak kullanılmak üzere boyunun $a-b$ $\mathrm{cm}$ aralığından seçilebildiği, proksimal çapı $16 \mathrm{~mm}$ ve distal çapı $7 \mathrm{~mm}$ olan bir çivi yapılanmasının geliştirilmesidir. Bu çap değerleri sayesinde ek kırık oluşması, kalınlık nedeni ile redüksiyonun bozulması, distalde stres yaratması ve ek kırık oluşturması gibi giriş yeri komplikasyonlarının en aza indirilmesi sağlanmaktadır.

Buluşun bir başka amacı, femur kemiğinin başına geçirilen proksimal sabitleme elemanları arasındaki mesafenin ayarlanması ile bahsedilen sabitleme elemanlarının femur boynu içerisinde kalmasının sağlanmasıdır. Bu sayede özellikle kısa hastalarda sıklıkla görülen ve sabitleme elemanlarının femur boynunun üst bölümünü yırtarak dışarı çıkması ya da kemik içerisinde yer kalmamasına bağlı olarak femur başına tek sabitleme elemanı yollama zorunluluğu komplikasyonlarının en aza indirilmesi amaçlanmaktadır.

Buluşun bir başka amacı ise anteversiyon kusuru nedeni ile femur başına giden sabitleme elemanlarının merkezlemesinin diğer çivi sistemlerinden çok daha hızlı ve etkin olarak sağlanabilmesidir. Bahsedilen anteversiyon açısının daha önceden belirlenmiş olması kırık redüksiyonunu bozan ek açı düzeltme işlemlerine gerek kalmamasını sağlamaktadır. 
Yukarıda bahsedilen amaçları gerçekleştirmek üzere buluş, birbiri ile bütünleşik proksimal parça ve distal parçaya sahip, bahsedilen proksimal parça üzerinde oluşturulan en az bir sabitleme elemanı yuvası ile distal parça üzerinde oluşturulan en az bir sabitleme elemanı yuvası ve bahsedilen yuvalardan takılarak sabitlemeyi sağlayan en az bir proksimal distal sabitleme elemanı içeren, kemik iliği kanalında yumuşak dokuya zarar vermeden uygulama yapılmasını sağlayan ve bahsedilen proksimal ve distal parçalar arasındaki mediolateral açının $\theta: 5^{\circ}$ olduğu, femur kemiği, trokanter bölge kırıklarında intramedüller olarak (kemik iliği kanalına) uygulanan bir trokanterik çivi olup;

- Bahsedilen çivinin kemik iliği kanalında ilerlemesi esnasında çiviye kılavuzluk yapan, distal parçanın uç kısmını oluşturan kılavuz uç,

- Femur kemiğinin eğiminin arttı̆̆ı noktalarda bahsedilen kılavuz ucun esnemesini ve kendi içine kapanmasını sağlayan, bu sayede çiviye ve kemiğe uygulanan baskıyı azaltan en az iki, tercihen dört parçadan oluşan kanat içermesi ve

- Bahsedilen distal sabitleme elemanının aksına göre (x ve z) düzleminde femur kemiğinin başına paralel olarak uygulanan proksimal sabitleme elemanı ile distal sabitleme elemanı arasındaki sabitleme açısı ( $\beta$ ) $15^{\circ}$ 'dir.

Bahsedilen amaçları geliştirmek üzere, kanatların kanal içerisinde eğimin arttığı noktalarda kapanmasını ve esnemesini sağlamak üzere kanatlar arasında oluşturulan açıklık içermektedir. Bununla birlikte, kanadın alt ucunda en az bir yanında olacak şekilde oluşturulan ve bahsedilen kanadın esneme kabiliyetini arttıran iç bükey oyuk bulunmaktadir.

Bahsedilen amaçları gerçekleştirmek üzere, proksimal sabitleme elemanının yuva içerisinde ilerlediği A-ekseni ile proksimal parçayı ortadan ikiye ayıran B-ekseni arasında, femur başına giden sabitleme elemanlarının merkezlemesini sağlayan A ekseni ile B ekseni arasındaki açıyı (" $\phi$ ” açısı) içermesidir. $B u$ " $\phi$ " açısı için denemeler sonucunda en sağglıkı uygulama değeri $125^{\circ}$ olarak belirlenmiştir.

Söz konusu çivi, arka kısmında bulunan açıklıktan yumuşak dokunun çivi içerisine girmesini önlemek amacı ile proksimal parçada tıkaç içermektedir.

Buluşun yapısal ve karakteristik özellikleri ve tüm avantajları aşağıda verilen şekiller ve bu şekillere atıflar yapılmak suretiyle yazılan detaylı açıklama sayesinde daha net olarak anlaşılacaktır ve değerlendirmenin de bu şekiller ve detaylı açıklama göz önüne alınarak yapılması gerekmektedir.”

\section{Referans Numaralarının Açıklamaları ${ }^{[1]}$}

\section{Trokanterik çivi}

\section{Proksimal parça}

100. Sabitleme elemanı yuvası
101. Proksimal sabitleme elemanı

102. Tikaç

11. Distal parça

110. Sabitleme elemanı yuvası

111. Distal sabitleme elemanı

112. Kılavuz uç

1120. Kanat

1121. Oyuk

1122. Açıklık

\section{Femur (uyluk kemiği)}

20. Gövde

21. Femur başı

22. Femur boynu

23. Trokanter bölge

X: Proksimal parçadaki sabitleme elemanı yuvaları arasındaki mesafe

A ekseni: Proksimal parçada bulunan sabitleme elemanı yuvasından geçen sabitleme elemanının izlediği eğimli eksen

B ekseni: Proksimal parçayı ikiye bölecek şekilde ortasından geçen eksen

ф: A ekseni ile B ekseni arasındaki açı

$\boldsymbol{\beta}$ : Anteversiyon açısı

$\boldsymbol{\theta}:$ Mediolateral açı

\section{Buluşun Detaylı Açıklanması ${ }^{[1]}$}

"Bu detaylı açıklamada, buluş konusu trokanterik çivinin (1) tercih edilen yapılanmaları, sadece konunun daha iyi anlaşılmasına yönelik olarak ve hiçbir sınırlayıcı etki oluşturmayacak şekilde açıklanmaktadır.

Şekil 1'de buluş konusu trokanterik çivinin (1) iki boyutlu temsili bir görünümü verilmektedir. Söz konusu buluş, femur kemiği (2) trokanter bölge (23) kırıklarında kanal içine uygulanmak üzere geliştirilen bir trokanterik çivi (1) ile ilgilidir. Bahsedilen çivi (1), proksimal parça (10) ve distal parça (11) olmak üzere birbiri ile irtibatı iki parçalı yapıdadır. Şekil 2 ve Şekil 3'te proksimal parçaya (10) ilişkin sırası ile yandan ve üstten kesit çizimler verilmektedir. Proksimal parça (10) üzerinde femur kemiğinin (2) uç kısmında yer alan femur başına (21) takılan proksimal sabitleme elemanlarının (101) geçtiği en az bir, tercihen iki sabitleme yuvası (100) bulunmaktadır. Bahsedilen yuvalar (100) arasında bir "X" mesafesi oluşturulmuştur. Bu "X” mesafesi, 5-15 mm arasında olup kullanılan proksimal vida ve çivinin proksimal kalınlığına göre değişebilmektedir. Buluşun bu uygulamasında $8 \mathrm{~mm}$ olarak seçilmiştir. Bu sayede her ikisi de kompresyon (baskı) yapma özelliğinde olan proksimal sabitleme elemanlarının (101) femur boynu (22) içerisinde kalması sağlanmaktadır. 
Bu ise özellikle kısa boylu hastalarda görülen ve sabitleme elemanının (101) femur kemiğinin (2) üst bölümünü yırtarak dışarı çıkmasını engellemektedir. Bununla birlikte " $X$ " mesafesi, femur boynunda (22) yer kalmamasından dolayı femur başına (21) tek sabitleme elemanı (101) gönderilmesi gereken durumların da önüne geçmektedir.

Dolayısılyla proksimal parçaya (10) iki adet sabitleme elemanı (100) gönderilmektedir. Femur başına (21) alt yarısına bir esas yük taşıyan bir sabitleme elemanı (101) ile femur başının (21) üst yarısına rotasyonu önlemek üzere bir sabitleme elemanı (101) gönderilmektedir. Bahsedilen sabitleme elemanları (101) tercihen 50-140 mm aralığındaki uzunluk değerlerine sahip olmaktadır. Proksimal parçadaki (10) yuvalardan (100) geçen sabitleme elemanları (101) ile kırık alanının kontrollü olarak sıkıştırılmasını sağlamaktadır.

Söz konusu sabitleme elemanları (101), yuvada (100) eğimli bir A ekseni hizasında ilerlemektedir. Şekil 2'de verildiği üzere bahsedilen A ekseni ile B ekseni arasında bir " $\phi$ " açısı oluşmaktadır. Bahsedilen " $\phi$ " açısı $125^{\circ}$ olup, sabitleme elemanı yuvaları (100) ile proksimal parçanın (10) arasındaki eğimi ifade etmektedir. " $\phi$ " açısı sayesinde özellikle kırıkların redüksiyonu sonrasında ortaya çıkan anteversiyon (femur başı (21) ve boynundan (22) geçen düzlem ile femur kondillerinden geçen düzlem arasındaki açı) kusuru nedeni ile femur başına (21) giden sabitleme elemanlarının (101) merkezlemesi çok daha hızlı ve etkin bir şekilde sağlanabilmektedir. Aynı zamanda bu açısal değerin önceden belirlenmiş olması sayesinde kırık redüksiyonunu bozabilecek ek açı düzeltmelerine gerek kalmamaktadır.

Proksimal parça (10) ile bütün olan distal parça (11) ise çivinin (1) kemik iliği kanalında ilerlemesinde çiviye (1) kılavuzluk yapan uç (112) kısmı kanatı (1120) bir yapıda oluşturulmuştur. Bahsedilen kanatlar (1120) buluşun tercih edilen bu uygulamasında 4 adet olup, farklı uygulamalarda değişik sayılarda olacak şekilde artabilmekte ya da azalabilmektedir. Bu kanatlar (1120) sayesinde çivi (1) medüller kanal içerisinde ilerletilirken esneyebilmekte, kanaldaki daralmalarda kanatların (1120) kapanabilmesi sayesinde stres yoğunlaşması en aza indirilmektedir. Söz konusu kanatlara (1120) esneklik özelliği, bu kanatlar (1120) arasında bulunan açıklık (1122) ile kazandırmaktadır. Bununla birlikte her kanadın (1120) distal parçaya (11) yakın kısmında olacak şekilde iki yanında oyuk (1121) bulunmaktadır. Bahsedilen oyuklar (1121), kanatların (1120) alt kısmını inceltmekte ve esneme kabiliyetini arttırmaktadır. Bu oyuklar (1121) ve kanatlar (1120) arasındaki açıklık (1122) sayesinde femur kemiğinin (2) eğiminin arttığı noktalarda kılavuz uç (112) kendi içerisine kapanabilmekte böylelikle kemik iliği kanalında daha rahat ilerlemektedir.

Distal parça (11), kılavuz ucun (112) başladığı nokta ile proksimal parça (10) arasında kalan kısmında distal parçanın (11) femur gövdesine (20) sabitlenmesine sağlamak üzere sabitleme elemanı yuvaları (110) bulunmaktadır.
Distal parça (11) üzerinde en az bir adet olacak şekilde tercihen 4 adet olan distal sabitleme elemanları (111) için yuvalar (110) oluşturulmuştur. Trokanterik çivinin (1), distal sabitleme elemanları (111) statik veya dinamik olarak kilitlenebilmektedir. Statik kilitleme ile özellikle çok parçalı kırıklarda kırık kaynamasının ilk dönemlerinde ihtiyaç duyulan mutlak stabilite sağlanırken, dinamik kilitlemede ise kırık hattında oluşmuş bulunan kaynama dokusunda hareket ile metabolik aktivite artı̆̆ı sağlanarak kaynamanın hızlandırılması amaçlanmaktadır.

Bahsedilen proksimal parça (10) ile distal parça (11) arasında $5^{\circ}$ 'lik bir " $\theta$ " açısı vardır. Bu " $\theta$ " açısı mediolateral açı olup hem distal parça (11) hem de proksimal parçayı (10) ilgilendirmektedir. Mediolateral plandaki bu açı değerinin $5^{\circ}$ olması, çivinin (1) kemik iliği kanalında ilerlerken kanal etrafindaki yumuşak dokulara zarar vermeden uygulanmasını sağlamaktadır. Bahsedilen " $\theta$ " açısı distal parça (11) ile proksimal parça (10) arasında oluşturulmasının sebebi, kemik iliği kanalında oluşan daralmalar ya da kemiğin (2) her bölgesinin aynı eğime sahip olmamasının bir sonucu olarak, buluş konusu çivinin (1) kanal içerisindeki hareketini kolaylaştırmakta ve çevresindeki yumuşak dokulara zarar vermesini önlemektedir.

Proksimal parça (10) femur kemiğinin (2) trokanter bölgesinden (23) geçerek gövde (20) içerisinde distal parça (11) ucundaki kılavuz uси (112) takip ederek ilerlemektedir. Bahsedilen çivi (1) kemiğe (2) tamamen girdikten sonra, çivinin (1) kemiğe (2) giriş ucunda proksimal parçanın (10) arka ucu bulunmaktadır. Buluş konusu trokanterik çivi (1) içi boş bir yapıdadır. Bundan dolayı, yumuşak dokunun çivi içerisine ilerlemesine engel olmak üzere bir tıkaçtan (102) faydalanılmaktadır.

Şekil 3'te buluş konusu trokanterik çivinin (1) anteversiyon açısının ( $\beta$ ) gösterildiği proksimal parçaya (10) ait üstten kesit görünüm verilmektedir. Bahsedilen $\beta$ açısı $15^{\circ}$ olup anatomik olarak verilen bu açı sayesinde çivinin pozisyonu hiç değiştirilmeden kılavuz telin femur başını tam merkezlemesi sağlanarak hem röntgen ışınına maruz kalınan süre azaltılmakta hem de ameliyat süresi ve kırığın redüksiyonunun devamlılığı sağlanmaktadır. Ви $\beta$ açısı, distal sabitleme elemanı (111) aksına göre ( $x$ ve z) düzleminde $15^{\circ}$ 'dir ve proksimal sabitleme elemanları (101) femur başına (21) uygulanmakta olup bahsedilen femur başına (21) paralel olarak sabitlenmektedir."

\section{İstemler ${ }^{[1]}$}

"1- Buluş, proksimal parça (10) ve distal parçaya (11) sahip, bahsedilen proksimal parça (10) üzerinde oluşturulan en az bir sabitleme elemanı yuvası (100) ile distal parça (11) üzerinde oluşturulan en az bir sabitleme elemanı yuvası (110) ve bahsedilen yuvalardan (100 ve 110) takılarak sabitlemeyi sağlayan en az bir proksimal ve distal sabitleme eleman (101 ve 111) içeren, 
kemik iliği kanalında yumuşak dokuya zarar vermeden uygulama yapılmasını sağlayan ve bahsedilen proksimal ve distal parçalar $(10,11)$ arasındaki mediolateral açının " $\theta$ " olduğu, femur kemiği (2) trokanter bölge (23) kırıklarında intramedüller olarak (kemik iliği kanalına) uygulanan bir trokanterik çivi (1) olup, özelliği;

- Bahsedilen çivinin (1) kemik iliği kanalında ilerlemesi esnasında çiviye (1) kılavuzluk yapan, distal parçanın (11) uç kısmını oluşturan kılavuz uç (112),

- Femur kemiğinin (2) eğiminin arttığı noktalarda bahsedilen kılavuz ucun (112) esnemesini ve kendi içine kapanmasını sağlayan bu sayede çiviye (1) ve kemiğe (2) uygulanan baskıyı azaltan en az iki parçadan oluşan kanat (1120) içermesi ve

- Çivinin pozisyonu (1) değiştirilmeden kılavuz telin femur başını tam merkezlemesi sağlanarak operasyon sırasında röntgen ışınına maruz kalınan sürenin azaltılmasını, operasyon süresinin azaltılmasını ve kırığın redüksiyonunun devamlılığını sağlayan, bahsedilen distal sabitleme elemanının (111) aksına göre ( $x$ ve z) düzleminde femur kemiğinin (2) başına (21) paralel olarak uygulanan proksimal sabitleme elemanı (101) ile distal sabitleme elemanı (111) arasındaki anteversiyon açısının $(\beta) 15^{\circ}$ olması

- Proksimal sabitleme elemanının (101) yuva (100) içerisinde ilerlediği $A-$ ekseni ile proksimal parçayı (10) ortadan ikiye ayıran B-ekseni arasında, femur başına (21) giden sabitleme elemanlarının (101) merkezlemesini sağlayan " $\phi$ " açısı içermesidir.

2- Istem 1'e uygun trokanterik çivi (1) olup, özelliği; distal parçanın (11) bahsedilen kılavuz ucunun (112) 4 kanatlı (1120) olmasıdır.

3- Istem 1 ve 2'ye uygun trokanterik çivi (1) olup, özelliği; kanatların (1120) kanal içerisinde eğimin arttı̆̆ı noktalarda kapanmasını ve esnemesini sağlamak üzere bahsedilen kanatlar (1120) arasında oluşturulan açıklık (1122) içermesidir.

4- İstem 1 ila 3'e uygun trokanterik çivi (1) olup, özelliği; kanadın (1120) alt ucunda en az bir yanında olacak şekilde oluşturulan ve bahsedilen kanadın (1120) esneme kabiliyetini arttıran iç bükey oyuk (1121) içermesidir.

5- İstem 1'e uygun trokanterik çivi (1) olup, özelliği; bahsedilen " $\phi$ " açısının $125^{\circ}$ olmasıdır.

6- İstem 1 ila 5'e uygun trokanterik çivi (1) olup, özelliği; proksimal parçanın (10) arka ucunda femur kemiğine (2) giriş kısmında bulunan ve çivinin (1) içerisinde yumuşak dokunun ilerlemesini önlemek üzere kullanılan tıkaç (102) içermesidir.

7- Istem 1'e uygun trokanterik çivi (1) olup, özelliği; femur başına (21) birbirine paralel olarak gönderilen proksimal sabitleme elemanları (101) arasındaki $X$ mesafesinin 5-15 $\mathrm{mm}$ arasında tercihen $8 \mathrm{~mm}$ olmasıdır."

\section{Şekillerin Kısa Açıklaması [1]}

Mevcut buluşun yapılanması ve ek elemanlarla birlikte avantajlarının en iyi şekilde anlaşılabilmesi için aşağıda açıklaması yapılan şekiller ile birlikte değerlendirilmesi gerekir.

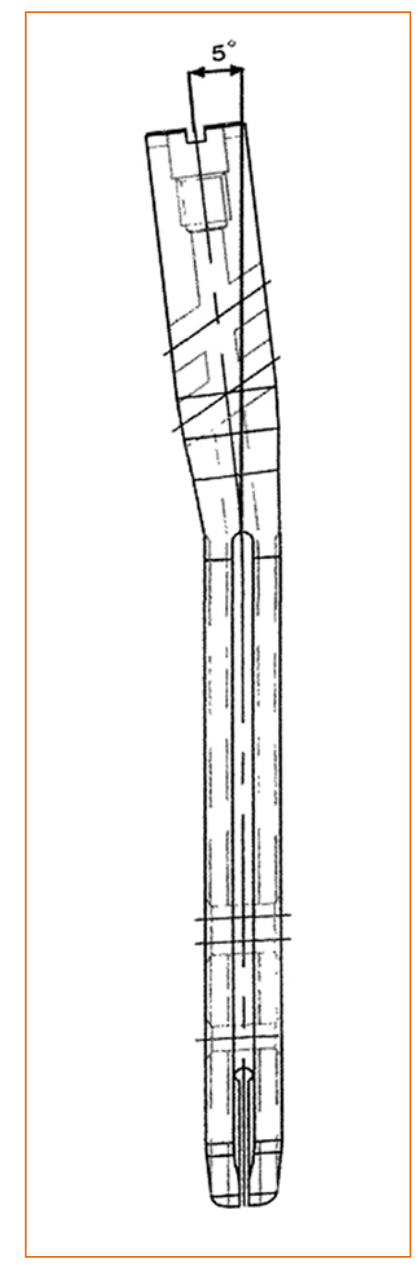

Şekil 1. Buluşun tercih edilen şekline uygun olarak geliştirilen ve kemiğe intramedüller olarak (kemik iliği boşluğuna) takılan bahsedilen trokanterik çivinin iki boyutlu, yandan görünümü verilmektedir.

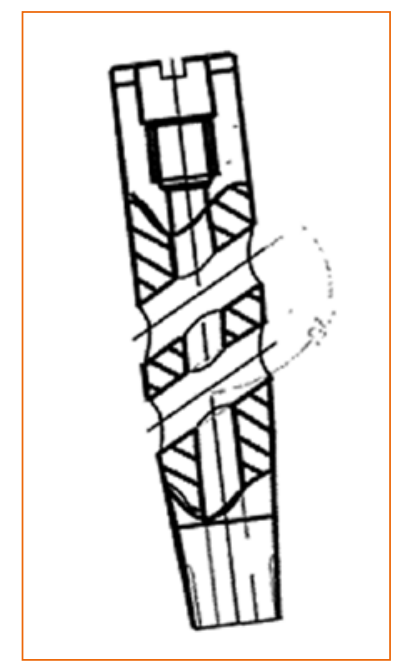

Şekil 2. Buluş konusu trokanterik çivinin proksimal parçasında bulunan sabitleme elemanı yuvalarının ve bu yuvadan geçen sabitleme elemanlarının geçiş ekseni ile diafiz (kemik gövdesi) arasındaki açı değerinin gösterildiği kesit görünümüdür.

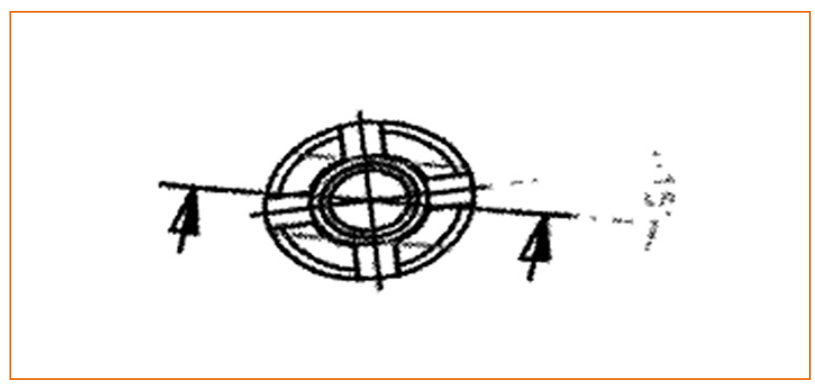

Şekil 3. Buluş konusu trokanterik çivide proksimal bölgenin üstten, iki boyutlu ve anteversiyon açısının gösterildiği görünümdür. 

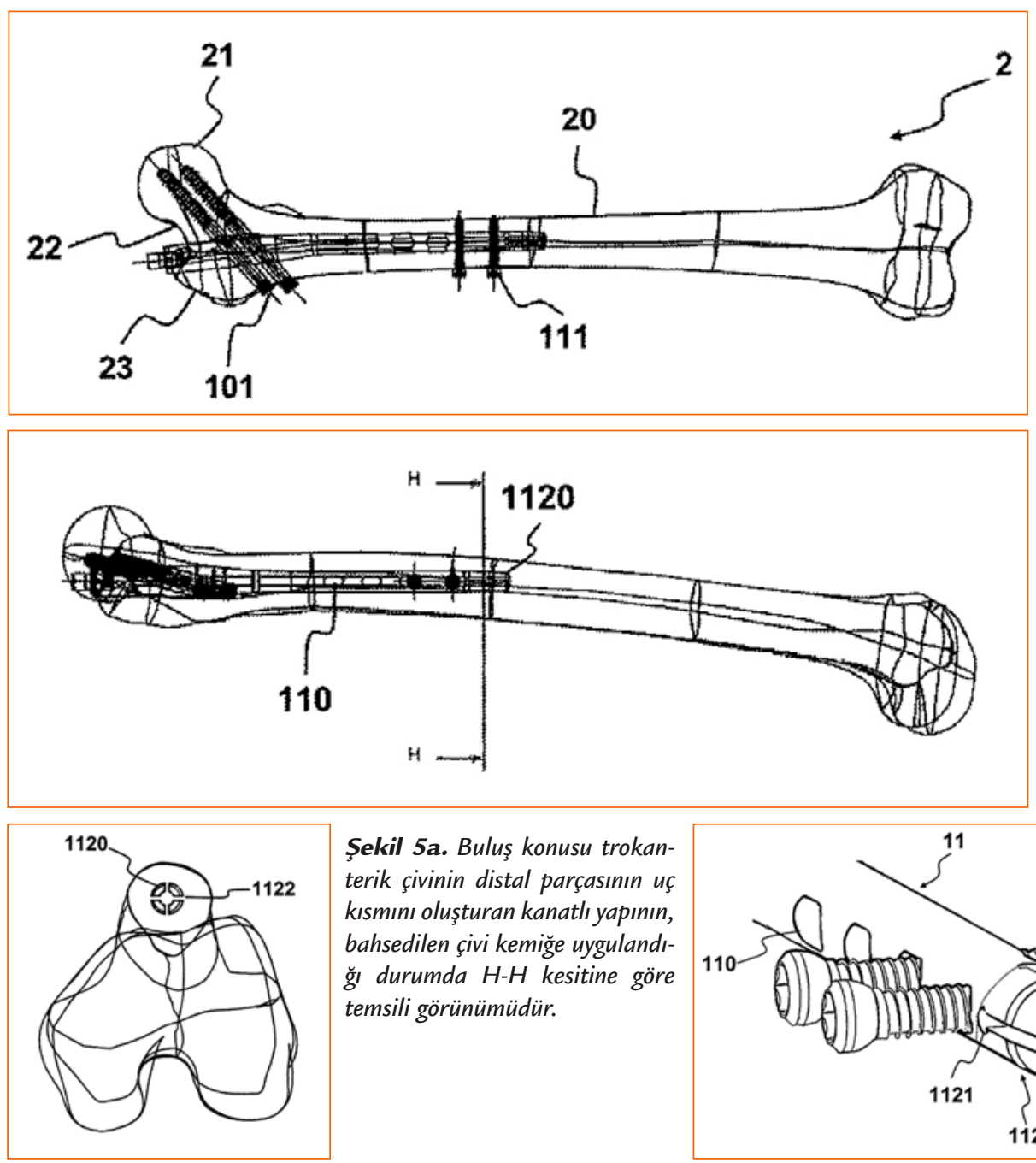

Şekil 5a. Buluş konusu trokanterik çivinin distal parçasının uç kısmını oluşturan kanatlı yapının, bahsedilen çivi kemiğe uygulandı$\breve{g}_{l}$ durumda $\mathrm{H}-\mathrm{H}$ kesitine göre temsili görünümüdür.

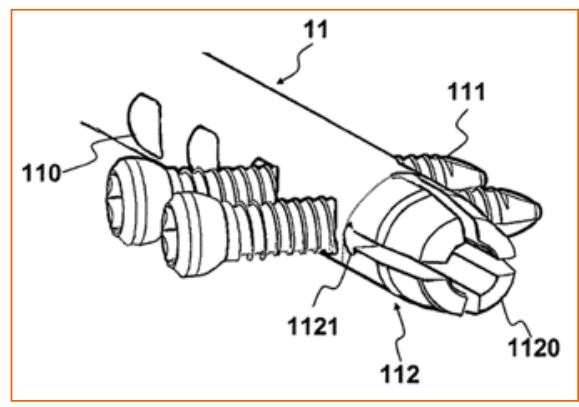

Şekil 5b. Buluş konusu trokanterik çivinin distal parçasının uç kısmını oluşturan kanatlı yapısının ve distal sabitleme elemanlarının yuvalar ile birlikte perspektif görünümüdür.

Çizimlerin mutlaka ölçeklendirilmesi gerekmemektedir ve mevcut buluşu anlamak için gerekli olmayan detaylar ihmal edilmiş olabilmektedir. Bundan başka, en azından büyük ölçüde özdeş olan veya en azından büyük ölçüde özdeş işlevleri olan elemanlar aynı numara ile gösterilmektedir.

\section{YAZARIN KONUYLA íGILI ÇALIŞMALARI|[2]}

Söylemez MS, Uygur E, Poyanlı O. Effectiveness of distally slotted proximal femoral nails on prevention of femur fractures during and after intertrochanteric femur fracture surgery. Injury 2019;50:2022-9.

\section{KAYNAKLAR}

1. Intramedüller olarak uygulanan trokanterik çivi. T.C. Türk Patent Enstitüsü. Patent Belgesi. No: 2011 05496. https:// portal.turkpatent.gov.tr/anonim/arastirma/patent/detayli

2. Söylemez MS, Uygur E, Poyanlı O. Effectiveness of distally slotted proximal femoral nails on prevention of femur fractures during and after intertrochanteric femur fracture surgery. Injury 2019;50:2022-9. Crossref 